\title{
Effects of Reengineering in Banks on Employees Perception of Job Security
}

\author{
Ademola B. Owolabi (Corresponding author) \\ Department of Psychology \\ Faculty of the Social Science \\ University of Ado-Ekiti, Nigeria \\ Tel: +234-806-670-8016Ｅ-mail: labdem2005@yahoo.ca \\ Benjamin O. Omolayo \\ Department of Psychology \\ Faculty of the Social Science \\ University of Ado-Ekiti, Nigeria
}

Received: October 14, 2011

doi:10.5430/jms.v2n4p95
Accepted: November 14, 2011 Published: December 15, 2011

URL: http://dx.doi.org/10.5430/jms.v2n4p95

\begin{abstract}
Banks in Nigeria are passing through a process of reorganizing how works are done in their organization with the aim of becoming more efficient and effective. This paper examines employees' perception of job security in response to re-engineering or technological changes in Banks. A job insecurity scale was use to measure employee perception to job insecurity. The scale was adapted from Ashford, Lee and Bobkos (1989) job insecurity scale and standardized by the researcher for the purpose of this research. A total of 150 participants (86 males and 64 females) were randomly drawn from two head office branches of Spring and Wema banks (Plc) respectively.

Four hypotheses were tested. Findings revealed that there was no significant effect of re-engineering on perception of job insecurity among banks employee. Significant relationship was, however, observed between age and job insecurity of employee, there was also significant effect of job status on job insecurity. The result also revealed a significant effect of gender on perception of job insecurity among bankers. The implication of these findings is that when worker have a good understanding of the process of reengineering through proper education that it does not connote job loss. This study has shown that some negative attitude display by worker in an organization were largely due to lack of proper education by management.
\end{abstract}

Key words: Organization; Productivity; Restructuring; Job satisfaction; Globalization

\section{Introduction}

Re-engineering first become known in the late 1980s and developed into one of the most important concepts discussed by organizations by the mid 1990s (Rigby, 2001). To be more competitive in the global environment, many organizations re-examined and restructured their operations to improve productivity. Reengineering involves a central rethinking,' extravagant redesign of business process and extreme operational changes that enhance productivity, especially cost effectiveness, quality and speedy service. In other words, re-engineering is about doing business faster, smarter, cost effective and better. The recently introduced label of efficiency through reengineering covers the adoption of radical means to achieve corrective actions. This extremism offers what appears to be instant relief from the pressures on corporate executives to show immediate improvements. Reengineering, as recently promoted, is a new label that covers some consultants' extraordinary claims that things can be done better. The process of reengineering means that there will be downsizing and rightsizing within the organization and how does this affect employees perception of the security of their job.

Hammer and Champy (1993) define what the best principle of the re-engineering is probably. They argued that since Adam Smith, companies have been organized around tasks. The post industrial company must according to them, reunify the tasks into coherent business processes. They insist on the necessity of revolutionary change in the way that 
companies think about business process.

In a re-engineering change, specializations are broken down and job and tasks become more flexible, functional barriers to natural sequences of tasks are removed as much as possible. Each worker can then function in nearly all the department. Unlike in traditional organization were there are established roles for people, permanent tasks and department. Organizational structure today has become flattered with each worker having more task to perform, more people to supervise and greater flexibility in job performance. When management declares that they are going to re-engineer, they are declaring that the relationship between people and their jobs are going to change, for at least the transition period.

In an attempt to cut costs, adapt to technological change and become more profitable, organizations have engaged in widespread layoffs and downsizing. These strategies are now being questioned because of empirical evidence suggesting that these aims are not necessarily achieved (Demeuse, Vanderheiden \& Bergmann, 1994). There are also evidence that increase in downsizing involves its possible effect on the family of affected worker (Barling, 1994). The loss of job associated with reengineering has become a chronic concern of Nigerian workers and there is tendency to feel insecure in ones job ones re engineering is mentioned. Job insecurity is a phenomenon that affect not only the individual at work, but also the individual outside work, and his or her organisation ( Sverke, Hellgren \& Naswall, 2006)

Job insecurity reflects the degree to which employees perceive their job to be threatened and feel powerless to do anything about it (Ashford, Lee, \& Bobko, 1989). Job insecurity affects employees own well-being and work functioning and its effect also go beyond the insecure employee, children of parents experiencing insecurity manifest social and school related problems. In a study that compare human service agencies perceived as stable and unstable, Quin and Lotempio (1989) found that rating of job insecurity were significantly related to the job dissatisfaction in the agency regarded as non stable but not in agency perceived as stable. Most studies such as Ferrie, Shipleya, Newman, Stansfeld and Marmot (2005), Lee, Colditz, Berkman, and Kawachi (2004) and De Cuyper and De Witte (2007) have established correlations between job insecurity and decrease in well-being.

Job insecurity as a perceptual factor is highly affected and determineed by the characteristic of the individual and his personal experience and context (Cheng and Chan, 2007).The question then is what is the perception of bankers in Nigeria about securing their jobs in the wake of reengineering or organizational changes?

Today, the concepts of globalization vis-a-vis, mobilization, privatization, devaluation and deregulation have arguably proved inefficient and killing. It has brought to Nigeria economy degradation vis-a-vis lowering the socio-economic status of Nigeria masses. Company mergers on acquisition have meant that countless workers have faced, or worse still may face the unexpected loss of their job which more often than not result in lower job satisfaction, especially, as there will be no visible alternatives after such a lost.

Studies have shown that job insecurity among employees leads to job dissatisfaction (Ashford, Lee and Bobko, 1989; Davy Kinicki and Sheek 1991), an increase negative physical health outcomes (Dooley, Rook \& Catalana 1987; Kuhnert, Sims and Lahey 1989; Rookeis and Louis-Guerin, 1990) and higher report of psychological distress (Dekker and Schaubeh 1995). Probst (2000), in addition, employees with perception of low job security are more likely to engage in withdrawal behaviour and report lower organization commitment (Ashford et. al., 1989; Davy et. al. 1991), which often leads to employee turnover. Although the effect of this rising job insecurity on employee's attitude, behaviours and physical and mental health outcome have been well-documented research on the implication of job insecurity for employee safety is visually non-existent. Heaney et al (1984) also discover that perception of job insecurity act as a chronic stressor whose effect becomes more potent as the time of exposure increases. Supporting the findings that job insecurity has dangerous effect, Sullivan (1998) wrote that increasing level of job insecurity created by changing employment relationship in Canada seem to lead to greater ill health in general population beyond direct effect of unemployment.

However, Kuhnert, Sims and Lahey (1989) reported studies examining the impact of lean production on employee safety, found detrimental effects on employees' health and injury rate in a variety of industries, including automobile, manufacturing, banking, telecommunication and healthcare. Though, these studies did not address job insecurity in particular, it is accepted that one of the hallmarks of lean production is the implementation of organizational downsize (American Management Association, 1997).

In a study conducted by Fischer et al (2005) the result showed that an important part of the working adolescents scored high on the scale of job insecurity which was explained in two way: they felt high level of psychological demand at the workplace or they believe that there job was at risk. How then, do employees perceive securities of their job in this wake of reengineering in the banking industry? 


\subsection{Objective of study}

In view of the statement above, this study aim at providing answers to the following questions

${ }^{*}$ what effect does reengineering have on employees perception of job insecurity

*would there be sex differences in the perception of job insecurity

*would there be an effect of job status on perception of job insecurity

*what effect does age have on perception of job insecurity

\section{Methods}

\subsection{Research Design}

The survey method as a research approach was employed. It was the best alternative considering the nature and type of study. As a researcher, i belief in the importance of empirical method as a way of collecting data about humans which can be quantified and statistically analyzed.

The two banks chosen for the study were very strategic to the study considering the fact that the two banks were in the process of reengineering the organization. They were specifically chosen because of the stages of reengineering in the organization.

The questionnaires were administered personally by the researcher to the banks employee through the assistance of the human resources managers of the banks. In responding to the instrument the participants were instructed to tick the response that best express their feeling in relation to the items in the scale. Confidentiality of their information was assured. Duration of 15 days was used for distribution and collection of the questionnaires. After the collection of the questionnaires sorting out the completed and uncompleted ones was done before the well-filed and complete 150 questionnaires was subjected to analysis.

\subsection{Sampling}

The purposive sampling method was used. A total of 150 participants were sample and used for the study, the sample was drawn from a population of two head office of Spring \& Wema banks in Lagos. The participants used were between the age of 28 and 49 years. Out of the 150 participant used for the final analysis 75 were drawn from Spring bank and 75 from Wema bank Plc, in which 86 out of them were males while the other 64 were females. The choice of these two banks for research is because of the recent restructuring and re-engineering processes that have been and are still being carried out, in the banks.

\subsection{Measuring Instrument}

A questionnaire made up of three sections was used. The first section of the questionnaire was designed to collect biographic information. It was drawn up to enable the determination of the participants, job status, age and gender. The second part of this questionnaire was adapted from Ashford, Lee and Bobkos (1998) job insecurity scale

Ashford, Lee \& Bobkos, (1980) developed their job insecurity scale based on the work of Greenhaigh and Rosenblatt (1984) with two sub-scale of threat and perceived powerlessness while the third section is a self developed questionnaire developed to measure employee's perception of reengineering processes going on in their organization.

Threat: This subscale is intended to capture an individual's perceived total job threat. The scale consists to ten items, which pose questions relating to the future possibility of job loss, retirement and re-employment. Responses are recorded by employing a five point liker format. The response formal ranges from "very likely" and to very unlikely". High score on the scale indicate a high-perceived threat to job, where a low score would represent a low perceived job threat. An alpha coefficient- of .75 has been reported by Ashford et.al (1989) for this subscale. The reliability of this subscale was also verified in a study conducted by Reevesit and yielded a standardize alpha of .71.

Perceived Powerlessness: The second sub-scale of job insecurity refers to employee's perceived powerlessness. It consists of three items with responses score on a five point liker scale, they range from "strongly agree" to "strongly disagree" individuals with a low score indicate a perception of powerlessness, while a high score denotes a sense of power to resist possible threat to ones job. However a test-retest reliability of the adapted questionnaire was done by the researcher. A correction coefficient of .98 was confirmed for the job insecurity resulted from administering the questionnaire to fifty six (56) bankers twice within two weeks.

\subsection{Data analyses}

The independent t-test was employed as a means of analyzing the data. It is the most appropriate considering the nature of the data. 


\title{
3. Results
}

Table 1: A t-test table showing effect of reengineering on job insecurity

\author{
<Table 1 about here>
}

Table 1 shows that there is no significant effect of re- engineering on job insecurity among bankers, $r=(148)=-11 p$ $<05$ hence hypothesis one is rejected. This means that reengineering does not lead to perception of job insecurity.

$<$ Table 2 about here $>$

Table 2: Independent t -test summary table showing the effect of sex on job insecurity

Table 2 shows that there is a significant effect of gender on job insecurity. Hence, the hypothesis which stated that there will be significant effect of gender on job insecurity is accepted $t=(148)=7.88$; $\mathrm{P}<.05$

Table 3: Independent t-test summary table showing the effect of job status on job insecurity.

$<$ Table 3 about here $>$

Table 3 shows that three is a significant effect of job status on job insecurity. Hence the hypothesis that states that there will be a significant difference between workers' job status and insecurity is supported. Low status workers however show more job insecurity than high status workers, hence the hypothesis is supported $t=(148)=$ 8.42; $\mathrm{P}<.05$

Table 4: Pearson r summary table showing the relationship between age and job insecurity.

$<$ Table 4 about here>

Table 4 shows that there is significant relationship between and job insecurity, hypothesis four is accepted, $\mathrm{r}=(148)=$ $0.54 ; \mathrm{P}<.05$. This shows that older employee feel more secure on their job than the young employee.

\section{Discussion}

This study was designed to examine the effect of re-engineering on employees' perception of job security in banks.

The first hypothesis showed that there is no significant relationship between re-engineering and job insecurity among Bankers, The result is contrary to the research outcome of Stevenson and Moldoveanu, (1995). This might be a result of the fact that workers have no realized that reengineering usually bringing new business opportunity with more hands needed to cope with the challenges. Several banking process that are now in place where not heard of before. There are western union money transferred, online banking, banks acting as agent of money collection, all this have increase the work, so, reengineering might requires more worker rather than reducing it, therefore it has no effect on job security. This shows that when management declares that they are going to re-engineer, they are declaring that the relationship between people and their job are going to change, for at least, the transition period. Re-engineering means that jobs will be more flexible, more complex and less predictable rather than that people will loose their jobs.

Hypothesis two stated that there is a significant effect of gender on job insecurity with women feeling more secured on their jobs. In most homes, men are the breadwinners who must source for the means of sustaining the family with basic things of life. Hence men perceive more' insecurity in their job than their female colleagues in banks. This opinion is however supported by Vroom et al, (1964). In his popular VIE theory postulated that the valence of certain outcomes may be derived in their own right, but more usually they are derived from other outcomes to which they are expected to lead. He asserts that this valence of outcome derive from their instrumentality.

Nigeria society men ought to be able to provide basic household needs, pay school fees of the children and be the head in the house. Hence any loss of job will mean a disorganization of home and career of the children. The impact of such loss may be minimal in women, however, hypothesis three showed significant effect of job status on job insecurity. Probably, due to fact that the more years one spent on a job, the greater the level of specialization and the lesser job mobility in Nigeria,. it is usually very difficult finding job especially for older people and highly placed employee who might not find themselves in the same status in another organization even when they can find job. The result of this research supports this literature.

These high status workers feel that pyramid height they have reached in their career is at stake during re-engineering process and hence perceived more insecurity of the job than the subordinates Their feelings are not in connect with the non-availability of good job in the labour market coupled with the fear to being unemployed.

There is also no significant relationship between age and job security. The implication of this is that age has significant relationship with perceived job insecurity. This clearly shows that there is a very stiff competition in the labour market. The young bankers know what it takes them to be employed into the banks while the older ones fears are directed at 
where to start again. Hence this result seems to be in the right direction putting into consideration the Nigeria factors.

\section{References}

America Management Association (1997). AMA survey on downsizing summary of key findings. AMACOM, New York, NY

Ashford, S. Y., Lee, C. L. \& Bobko, P. (1989). Content causes \& consequences of Job insecurity: A theory-based measure \& substantive test. Academy of Management Journal, 32, 803,-829.

Cheng, G. \& Chan, D. (2007). Who suffers more from job insecurity? A meta-analytical Review. Applied Psychology: An International Review, 57, 2, 272-303

Davy, J. A, Kninicki, A. J. \& Sheek, C. L. (1991). Developing \& testing a model of survivor response to layoff. Journal of Vocational Behaviour, 38, 302-317

De Cuyper, N. \& De Witte, H. (2006). Autonomy \& work load among temporary workers:their effect on job satisfaction, organisation commitment, life satisfaction \& self rated performance. International Journal of Strees Management 13, 4, pp.441-459

De Cuyper, N. \& De Witte, H. (2007). Job insecurity in temporary versus permenent worker: association with attitudes well-being \& behaviour. Work \& Strees 21, 1 pp.65-84.

Deeker, S.N.A. \& Schaubeh W.B. (1995). The effects of Job insecurity on psychological health \& withdrawal: A longitudinal study. Australian Psychologist, 30, 57-63

Dooley, D., Rook, K. \& Catalano, R. (1987). Job \& non job stressors \& their moderators. Journal of Occupational Psychology Vol 60 N0 2 PP 115-32

Ferrie, J., Shipleya, M., Newman, K., Stansfeld, S., \& Marmot, M. (2005). Self reported job insecurity \& health in the whitehall II study: potential explanation of relationship. Social Science \& Medicine,8 155-177.

Fischer, F., Oliveira, D., Nagai, R., Teixeira, L., Lombardi, J. M., Latorre, M. \& Cooper, S. (2005). Job control, job demand \& social support at work \& health among adolescent workers. Revista Saude Publica, 39, 2, 245-253

Greenhaigh, L. \& Rosenblatt, Z. (1984). Job insecurity: Toward conceptual clarity. Academy of Management Review, 9 438-748

Hammer, M. \& Champy, J. (1993). Re-engineering the corporation-A Manifesto for business transformation. Nicholas Brearley Punishing Ltd.

Kuhnert, K. W., Sims, R. R. \& Lahey, M. A. (1989). The relationship between job security \& employee health. Group \& Organisational Studies, 14 (4). 399-410

Lee, S., Colditz, G., Berkman, L, \& Kawachi, I. (2004 ). Prospective Study of job insecurity \& coronary hearth Disease in us women. Annual Epidemiology, 14, 24-30

Probst, G. J. B. (2000). Managing knowledge: Building blocks for success. John Wiley \& Sons, London.

Rokies, E. \& Louis-Guerin, C. (1990). Job insecurity in managers: Antecedent \& consequences. Journal of Organizational Behavior, 11, 345-359.

Rigby, D. (2001). Management tools \& techniques: A survey California. Management Review. No.2, pp.139-160.

Stvenson, H. H. \& Moldovean, U. M. C. (1995). The power of predictability. Harvard Business Review 73, 4, pp.140-143.

Sverke, M., Hellgren, J. \& Naswall, K. (2006). Job security: A literature review: (Report 1). Stockholm: National Institute for Working Life.

Vroom, V. (1964). Work \& Motivation. New York Wiley. 
Table 1.

\begin{tabular}{|l|l|l|l|l|ll|ll|}
\hline Variable & $\mathrm{N}$ & $\mathrm{X}$ & $\mathrm{SD}$ & $\mathrm{Df}$ & $\mathrm{t}-$ & $\mathrm{t}$ & $\mathrm{P}$ & $\mathrm{p}$ \\
\hline Reengineering & 150 & 48 & 12.33 & \multirow{2}{*}{148} & -11 & \multicolumn{2}{|c|}{$>.05$} & \\
\hline Job insecurity & 150 & 47 & 11.56 & & & & & \\
\hline
\end{tabular}

Table 2.

\begin{tabular}{|l|l|l|l|l|l|l|}
\hline Variable & $\mathrm{N}$ & $\mathrm{X}$ & $\mathrm{SD}$ & $\mathrm{Df}$ & $\mathrm{t}$-cal & $\mathrm{P}$ \\
\hline Female & 64 & 70.86 & 14.03 & 148 & 7.88 & $<.05$ \\
\hline Male & 86 & 54.49 & 11.39 & & & \\
\hline
\end{tabular}

Table 3.

\begin{tabular}{|l|l|l|l|l|l|l|}
\hline Variable & $\mathrm{N}$ & $\mathrm{X}$ & $\mathrm{SD}$ & $\mathrm{Df}$ & $\mathrm{t}-\mathrm{t}$ & $\mathrm{P}$ \\
\hline Low status & 62 & 71.56 & 10.76 & \multirow{2}{*}{148} & 8.42 & $<.05$ \\
\cline { 1 - 5 } High status & 88 & 54.36 & 13.32 & & & \\
\hline
\end{tabular}

Table 4.

\begin{tabular}{|l|l|l|l|l|l|l|}
\hline Variable & $\mathrm{N}$ & $\mathrm{X}$ & $\mathrm{SD}$ & $\mathrm{Df}$ & $\mathrm{r}$ & $\mathrm{P}$ \\
\hline Old & 150 & 63.00 & 14.49 & & 0.54 & $<.05$ \\
\hline Young & 150 & 36.60 & 7.12 & 148 & & \\
\hline
\end{tabular}

